\title{
Bronchopneumonia in wild boar (Sus scrofa) caused by Rhodococcus equi carrying the VapB type 8 plasmid
}

\author{
Agueda Castagna de Vargas ${ }^{1 *}$, Fernanda Monego², Letícia Trevisan Gressler ${ }^{1}$, Sônia de Avila Botton?, \\ Andrea Maria Lazzari ${ }^{3}$, Mateus Matiuzzi da Costa ${ }^{4}$, Roselene Ecco ${ }^{5}$, Márcio Garcia Ribeiro ${ }^{6}$, \\ Gustavo Henrique Batista Lara ${ }^{6}$ and Shinji Takai ${ }^{7}$
}

\begin{abstract}
Background: Rhodococcus equi is associated with pyogranulomatous infections, especially in foals, and this bacterium has also emerged as a pathogen for humans, particularly immunocompromised patients. R. equi infections in pigs, wild boar (Sus scrofa) and humans are mainly due to strains carrying the intermediate virulence (VapB) plasmid. In Brazil, R. equi carrying the VapB type 8 plasmid is the most common type recovered from humans co-infected with the human immunodeficiency virus (HIV). R. equi infection in pigs and wild boar is restricted predominantly to the lymphatic system, without any reports of pulmonary manifestations.

Findings: This report describes the microbiological and histopathological findings, and molecular characterization of $R$. equi in two bronchopneumonia cases in wild boar using PCR and plasmid profile analysis by digestion with restriction endonucleases. The histological findings were suggestive of pyogranulomatous infection, and the plasmid profile of both $R$. equi isolates enabled the characterization of the strains as VapB type 8.

Conclusions: This is the first report of bronchopneumonia in wild boar due to $R$. equi. The detection of the $\operatorname{VapB}$ type 8 plasmid in $R$. equi isolates emphasize that wild boar may be a potential source of pathogenic $R$. equi strains for humans.
\end{abstract}

Keywords: Rhodococcus equi, Wild boar (Sus scrofa), VapB plasmid, Bronchopneumonia

\section{Findings}

\section{Background}

Rhodococcus equi is a well-recognized gram-positive facultative intracellular pathogen. It primarily infects domestic animals, particularly foals. $R$. equi has also emerged as an opportunistic pathogen of humans, particularly immunocompromised patients $[1,2]$. The bacterium has been isolated from the feces and intestines of various herbivorous and omnivorous species, including cattle, sheep, horses, deer, goats, and pigs [3,4]. The most common manifestation of rhodococcosis in humans and animals is a progressive pyogranulomatous

\footnotetext{
* Correspondence: agueda.vargas@gmail.com

${ }^{1}$ Department of Preventive Veterinary Medicine, Universidade Federal de Santa Maria, UFSM, 97105-900, Santa Maria, State of Rio Grande do Sul, Brazil Full list of author information is available at the end of the article
}

bronchopneumonia, characterized by purulent abscesses and cavitation [3].

The virulence of $R$. equi is attributed to several factors, including a capsule, cholesterol oxidase and, in particular, plasmid-encoded virulence-associated proteins (Vaps) [1]. These plasmids determine the pathogenicity of $R$. equi, as they are associated with the survival of the bacterium inside macrophages [3]. Three levels of virulence of $R$. equi are recognized: virulent (VapA), intermediately virulent (VapB) and avirulent. Virulent $R$. equi strains are predominantly found in horses, whereas intermediate virulence isolates have been more often observed in pigs [5], HIV-positive human patients [6], and, recently, in wild boar with and without lymphadenitis $[7,8]$. The avirulent R. equi strains do not express VapA or VapB [9]. The VapB plasmids contains vapB and other vap genes (vap), vapK1, vapK2, and vapM) [10,11].

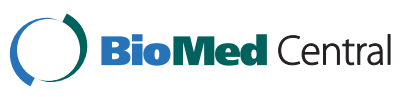


In Brazil, the first wild boar (Sus scrofa) bred for commercial purposes were introduced into the state of Rio Grande do Sul from Europe approximately in 1980 [12]. They were subsequently introduced into other Brazilian states as the commercialization of wild boar meat production increased. This report describes the first case of bronchopneumonia in wild boar caused by R. equi carrying a VapB type 8 plasmid.

\section{Materials and methods \\ Ethical statement}

The present study was approved by Ethical Committee of Animals (number 192/09-CEUA), of School of Veterinary Medicine and Animal Science - UNESP, Botucatu, SP, Brazil.

\section{Animals}

Two 70 to 80-day-old wild boar from a breeding farm in Distrito Federal (DF), Brazil, showed clinical signs of pulmonary infection. The animals had exhibited delayed physical developmental, decreased appetite, lethargy, persistent coughing, difficulty breathing, body temperature approximately of $40^{\circ} \mathrm{C}$ and râles of moderate intensity on thoracic auscultation. Samples of the lungs and pulmonary lymph nodes were collected at necropsy and subjected to microbiological and histopathological analyses.

\section{Diagnosis methods}

For histopathology, the specimens were fixed in $10 \%$ neutral buffered formalin and, embedded in paraffin, and the sections were stained with hematoxylin and eosin (HE). The lung samples of both animals were cultured, and bacterial identification was based on the observed morphological, staining and biochemical characteristics [13]. The results were confirmed using an $R$. equispecific polymerase chain reaction (PCR), as previously described [14]. Bacterial DNA was obtained from a pure colony suspended in $100 \mu \mathrm{L}$ of Milli-Q water, boiled for 7 minutes and centrifuged at $60,000 \times \mathrm{g}$ for 4 minutes [15] A second PCR was used to identify the virulenceassociated genes of the isolates, as described previously [16]. Primer 1 (5'-ACAAGACGGTTTCTAAGGCG-3') and primer 2 (5'-TTGTGCCAGCTACCAGAGCC-3') were used to detect the virulent (vapA gene) strains by amplifying a 550-bp product. Primer 3 (5'-GAATTCGA AAGCGCAAAGGT-3') and primer 4 ( $5^{\prime}$-TTCCGTGAAC ATCGTACTGC - $3^{\prime}$ ) were used to amplify a 650 -bp product from intermediately virulent ( $\mathrm{vapB}$ gene) isolates. The virulent strain ATCC 33701p and a human isolate previously characterized as vapB-positive were used as the positive controls in all the PCR reactions.

The plasmid types were determined by digestion with restriction endonucleases. $R$. equi plasmid DNA was isolated using a modified alkaline lysis method [17], as described previously [18]. The Plasmid DNA was digested with the restriction endonucleases EcoRI, EcoT22I and HindIII [19]. The fragments were fractionated on 1.0\% agarose gels, stained with ethidium bromide and examined under ultraviolet light.

\section{Results}

\section{Pathology}

At necropsy, the lungs were found to have multifocal to coalescent areas and granulomatous lesions, with dark-red consolidated areas in the cranial lobes and the ventral portion of the caudal lobes (Figure 1), and mucupurulent exudates in the bronchial lumina. The histological examinations revealed marked neutrophil infiltration into the bronchial and bronchiolar lumina. Large areas of necrosis, with bacterial colonies surrounded by degenerate neutrophils, epithelioid macrophages were also observed in the cranial lung lobes (Figure 2). Numerous foamy macrophages and neutrophils within the alveoli and chronic marked bronchopneumonia were also observed. The histological changes observed in the lungs and pulmonary lymph nodes were suggestive of $R$. equi infection [20].

\section{Bacterial isolation and molecular characterization}

$R$. equi was isolated from the lungs of both boar, and no other bacteria were isolated. The $R$. equi isolates from both wild boar were $\operatorname{vap} \mathrm{B} R$. equi.

\section{Plasmid characterization}

The plasmid profile of both $R$. equi isolates were those of VapB type 8.

\section{Discussion}

$R$. equi infections in wild boar cause lesions that are similar to those observed in rhodococcosis in pigs, and are generally restricted to the lymphatic tissues,

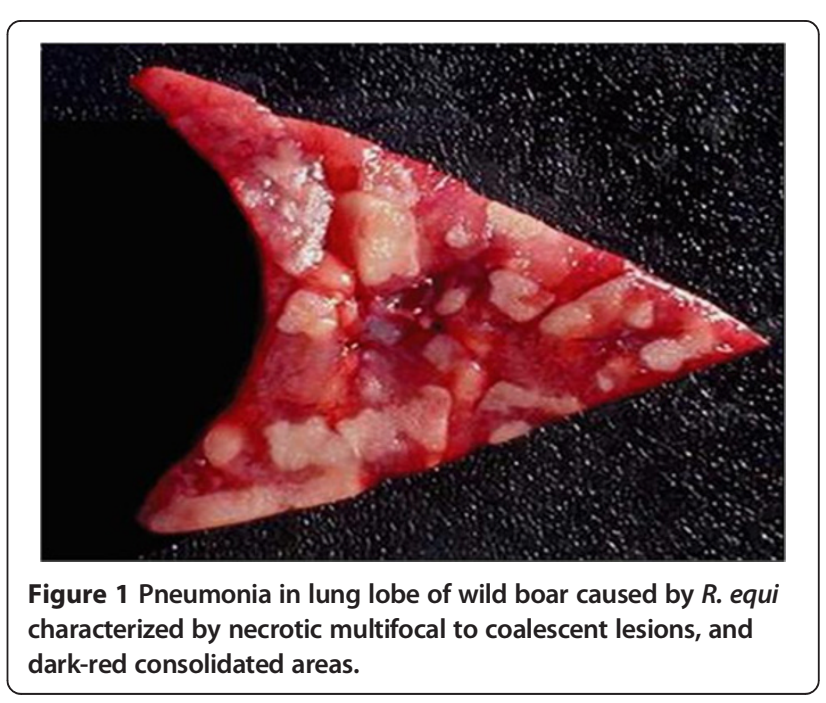




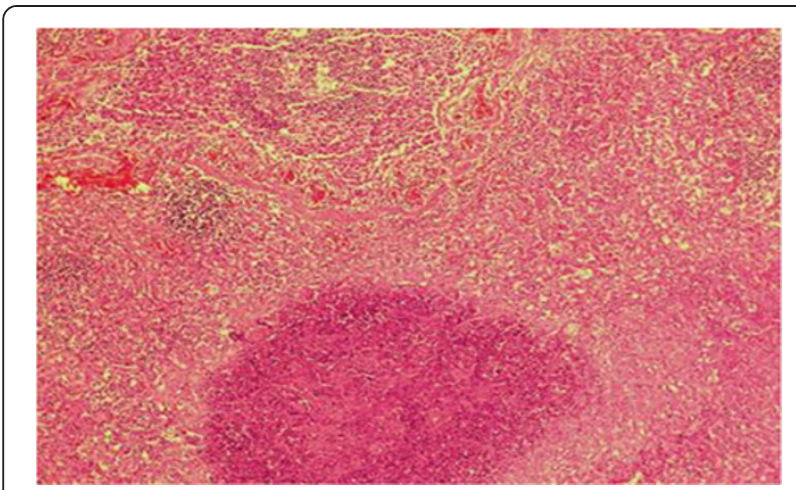

Figure 2 Necrotic bronchopneumonia caused by $R$. equi in the cranial lung lobe from a wild boar. Note area of necrosis containing micro-organisms surrounded by degenerate neutrophils, epithelioid cells and macrophages (Hematoxylin and eosin, 100X). involving the cervical and submaxillary lymph nodes, and the tonsils [11,21]. $R$. equi infection in pigs is associated with immunosuppression and co-infections with other pathogens [4], although $R$. equi have been isolated from swine with and without lymphadenitis [8,22]. In the cases describe herein, $R$. equi was identified as a primary cause of pulmonary lesions in the wild boar. Intermediately virulent $R$. equi strains are commonly found in submandibular lymph nodes in pigs, immunosuppressed humans [5], and more recently, wild boar [7,8]. In Hungary, $R$. equi was isolated from $14 \%$ and $12.4 \%$ of the submaxillary lymph nodes of pigs and wild boar, respectively [7,21], and these studies found the $v a p B$ gene in $26.8 \%$ of the $R$. equi isolates from pigs [21] and 25.6\% from wild boar [7]. In Japan, vapB-positive $R$. equi were isolated with high prevalence from 368 (93.9\%) lymph nodes from pigs [23]. Another study in Japan, described recently isolation of 45 (52\%) R. equi strains from submaxillary lymph nodes of 86 wild boar. From these strains were found vapB-positive in $21(24.0 \%)$ strains, predominantly types 2,1 and 4 plasmids, while vapA gene was found in $1(1.0 \%)$ strain, and $23(27.0 \%)$ remaining isolates were avirulent [24]. Currently, a Brazilian study of the virulence genes and plasmid profiles of the $R$. equi isolates from the lymph nodes of slaughtered wild boar found that $63.2 \%$ of the isolates contained the $v a p B$ gene, and the majority was identified as carrying type 8 plasmids [8]. Interestingly, this same plasmid profile (VapB type 8 ) is the one most frequently found in HIV-positive patients in Brazil [25], suggesting the zoonotic potential of $R$. equi isolates from wild boar. However, the human with rhodococcosis generally have no history of contact with pigs, wild boar or the environments of these species [25]. It is possible that the consumption of undercooked pig and wild boar products may be a route of infection with $R$. equi in humans in some countries $[6,8,24,25]$.

\section{Conclusions}

This is the first report of R. equi causing bronchopneumonia in wild boar. Although the role of domestic animals and wildlife in the transmission of $R$. equi to humans remains unclear, the detection of $R$. equi carrying a VapB type 8 plasmid in wild boar emphasizes the possibility that this species may be a potential source of virulent $R$. equi in humans, due to this plasmid profile has been identified in $R$. equi isolates from humans.

\section{Availability of supporting data}

The data set supporting this short report are contain in paper.

\section{Abbreviations}

bp: Base pairs; DNA: Deoxyribonucleic acid; HE: Hematoxylin eosin; HIV: Human immunodeficiency virus; PCR: Polymerase chain reaction; Vap: Virulence-associated proteins.

\section{Competing interests}

The authors declare that there are no conflicts of interest in this work.

\section{Authors' contributions}

This case report was written by ACV, FM, LTG and SAB. It was reviewed by all the authors, particularly MGR and GHBL. Microbiological culture and phenotypic identification were performed by CCK, MMC and AML. Clinical and histopathological examination of animals were performed by RE. Determination of the plasmid types of the $R$. equi isolates was carried out by ST, FM and MGR. All authors read and approved the final version of the manuscript.

\section{Acknowledgements}

We thank the Cristina Krewer for analysis and interpretation of data and manuscript review. The authors acknowledge the financial support from CNPq (Conselho Nacional de Desenvolvimento Científico e Tecnológico from Brazil) for: Letícia Gressler Master of Science Scholarship (130023/2012-4); Agueda Castagna Vargas Research Productivity Grant (313599/2009-2) and for the financial support awarded from Universal Grant 14/2011 (481943/ 2011-0).

\section{Author details}

'Department of Preventive Veterinary Medicine, Universidade Federal de Santa Maria, UFSM, 97105-900, Santa Maria, State of Rio Grande do Sul, Brazil. ${ }^{2}$ Department of Microbiology, Universidade do Contestado- UnC, Santa Catarina, Brazil. ${ }^{3}$ Department of Veterinary Medicine, União Pioneira de Integração Social - UPIS, Brasília, Brazil. ${ }^{4}$ Department of Veterinary Medicine, Universidade Federal do Vale do São Francisco - UNIVASF, Petrolina, State of Pernambuco, Brazil. ${ }^{5}$ Department of Veterinary Clinic and Cirugic, School of Veterinary, Universidade Federal de Minas Gerais -UFMG, State of Minas Gerais, Brazil. ${ }^{6}$ Department of Veterinary Hygiene and Public Health, School of Veterinary Medicine and Animal Sciences, Universidade Estadual Paulista UNESP, Box 560, Code 18618-970, Botucatu, State of Sao Paulo, Brazil. ${ }^{7}$ Department of Animal Hygiene, School of Veterinary Medicine and Animal Sciences, Kitasato University, Kitasato, Japan.

Received: 9 November 2012 Accepted: 18 March 2013 Published: 25 March 2013

\section{References}

1. Meijer WG, Prescott JP: Rhodococcus equi. Vet Res 2004, 35:383-396.

2. Puthucheary SD, Sangkar V, Hafeez A, Karunakaran R, Raja NS, Hassan HH: Rhodococcus equi - an emerging human pathogen in immunocompromised hosts: a report of four cases from Malaysia, Southeast Asian. J Trop Med Public Health 2006, 37:157-161.

3. Prescott JF: Rhodococcus equi: an animal and human pathogen. Clin Microbiol Rev 1991, 4:20-34. 
4. Hondalus MK: Pathogenesis and virulence of Rhodococcus equi. Vet Microbiol 1997, 56:257-268.

5. Takai S, Fukunga N, Ochiai S: Identification of intermediately virulent Rhodococcus equi isolates from pigs. J Clin Microbiol 1996, 34:1034-1037.

6. Takai S, Tharavichitkul P, Takarn P, Khantawa B, Tamura M, Tsukamoto A, Takayama S, Yamatoda N, Kimura A, Sasaki Y, Kakuda T, Tsubaki S, Maneekarn N, Sirisanthana T, Kirikae T: Molecular epidemiology of Rhodococcus equi of intermediate virulence isolated from patients with and without acquired immune deficiency syndrome in Ching Mai, Thailand. J Infect Dis 2003, 188:1717-1723.

7. Makrai L, Kobayashi A, Matsuoka M, Sasaki Y, Kakuda T, Dénes B, Hajtós I, Révész I, Jánosi K, Fodor L, Varga J, Takai S: Isolation and characterization of Rhodococcus equi from submaxillary limph nodes of wild boar (Sus scrofa). Vet Microbiol 2008, 131:318-323.

8. Ribeiro MG, Takai S, Guazzelli A, Lara GHB, Silva AV, Fernandes MC, Condas $L A$, Siqueira AK, Salerno T: Virulence genes and plasmid profiles in Rhodococcus equi isolates from domestic pigs and wild boar (Sus scrofa) in Brazil. Res Vet Sci 2011, 91:478-481.

9. Ribeiro MG, Seki I, Yasuoka K, Kakuda T, Sasaki Y, Tsubaki S, Takai S Molecular epidemiology of virulent Rhodococcus equi from foals in Brazil: virulence plasmids of 85-kb type I, 87-kb type I, and a new variant, 87-kb type III. Comp Immunol Microbiol Infect Dis 2005, 28:53-61.

10. Letek M, Ocampo-Sosa AA, Sanders M, Fogarty U, Buckley T, Leadon DP, González P, Scortti M, Meijer WG, Parkhill J, Bentley S, Vázquez-Boland JA: Evolution of the Rhodococcus equi vap pathogenicity island seen through comparison of host-associated vapA and vapB virulence plasmids. J Bacterio/ 2008, 190:5797-5805.

11. Von Bargeen K, Haas A: Molecular and infection biology of the horse pathogen Rhodococcus equi. FEMS Microbiol Rev 2009, 33:870-891.

12. Spitz F: The Atlas of European Mammals. London: T \& AD Poyser Natural History; 1999.

13. Quinn PJ, Carter ME, Markey B, Carter GR: Clinical Veterinary Microbiology. London: Wolfe; 1994

14. Bell KS, Philp JC, Christofi N, Aw DW: Identification of Rhodococcus equi using the polymerase chain reaction. Lett Appl Microbiol 1996, 23:72-74.

15. Sambrook R, Russel DW: Molecular Cloning: a laboratory manual. New York: Cold Spring Harbor Laboratory Press; 2001.

16. Monego F, Maboni F, Krewer C, Vargas A, Costa M, Loreto E: Molecular characterization of Rhodococcus equi from horse-breeding farms by means of multiplex PCR for the vap gene family. Curr Microbiol 2009, 58:399-403.

17. Birnboim HC, Doly J: A rapid alkaline extraction procedure for screening recombinant plasmid DNA. Nucleic Acids Res 1979, 7:1513-1523.

18. Takai S, Ikeda T, Sasaki Y, Watanabe Y, Ozawa T, Tsubaki S, Sekizaki T: Identification of virulent Rhodococcus equi by amplification of gene coding for 15-17-kDa antigens. J Clin Microbiol 1995, 33:1624-1627.

19. Takai S, Imai Y, Fukumaga N, Uchida Y, Kamisawa K, Sasaki Y, Tsubaki S, Sekizaki T: Identification of virulence-associated antigens and plasmids in Rhodococcus equi from patients with AIDS. I Infect Dis 1995, 172:1306-1311.

20. Madarame H, Takai S, Matsumoto C, Minamiyama K, Sasaki Y, Tsubaki S, Hasegawa Y, Nakane A: Virulent and avirulent Rhodococcus equi indection in T-cell deficient athymic nude mice: pathologic, bacteriologic and immunologic responses. FEMS Immunol Med Microbiol 1997, 17:251-262.

21. Makrai L, Takayama S, Dénes B, Hajtós I, Sasaki Y, Kakuda T, Tsubaki S, Major A, Fodor L, Varga J, Takai S: Characterization of virulence plasmids and serotyping of Rhodococcus equi isolates from submaxillary lymph nodes of pigs in hungary. J Clin Microbiol 2005, 43:1246-1250.

22. Lara GHB, Ribeiro MG, Leite CQF, Paes AC, Guazzelli A, Silva AV, Listoni FJP: Occurrence of Mycobacterium spp and other pathogens in lymph nodes of slaughtered swine and wild boar (Sus Scrofa). Res Vet Sci 2011, 90:185-188.

23. Takai S, Tsubaki S: The incidence of Rhodococcus (Corynebacterium) equi in domestic animals and soil. J Vet Med Sci 1985, 47:1291-1293.
24. Sakai M, Ohno R, Higuchi C, Sudo M, Suzuki K, Sato H, Maeda K, Sasaki Y, Kakuda T, Takai S: Isolation of Rhodococcus equi from wild boar (Sus scrofa) in Japan. J Wildelife Dis 2012, 48:815-817.

25. Ribeiro MG, Takai S, Vargas AC, Mattos-Guaraldi AL, Camello TCF, Silva AV: Identification of virulence associated plasmids in Rhodococcus equi from humans with and without acquired immune deficiency syndrome in Brazil. Am J Trop Med Hyg 2011, 85:510-513.

doi:10.1186/1756-0500-6-111

Cite this article as: de Vargas et al:: Bronchopneumonia in wild boar (Sus scrofa) caused by Rhodococcus equi carrying the VapB type 8 plasmid. BMC Research Notes 2013 6:111.

\section{Submit your next manuscript to BioMed Central and take full advantage of:}

- Convenient online submission

- Thorough peer review

- No space constraints or color figure charges

- Immediate publication on acceptance

- Inclusion in PubMed, CAS, Scopus and Google Scholar

- Research which is freely available for redistribution 